\title{
FORCE MAJEURE DAN NOTOIR FEITEN ATAS KEBIJAKAN PSBB COVID-19
}

\author{
Sufiarina $^{1}$, Sri Wahyuni ${ }^{2}$
}

\begin{abstract}
The Covid-19 outbreak as a pandemic that spreads rapidly and massively. The only way to break the chain of transmission is through restrictions on the movement of people. The Government of Indonesia has implemented a Large-Scale Social Limitation policy in Government Regulations No. 21 Tahun 2020 to protect the public. On the other hand, the enactment of the Covid-PSBB policy actually created economic difficulties for some groups of people. Such as transportation companies, tourism, hotels, restaurants and daily traders. Not a few companies that do layoffs or lay off employees. Economic difficulties has a result of the implementation of the agreement which had previously been running smoothly, suddenly can no longer be fulfilled because the debtor experienced a reduction or even loss of income. Various obligations under the agreement can no longer be fulfilled. The law considers things that cause the agreement not to be fulfilled because of default or because of force majeure. It is necessary to examine whether PSBB Covid-19 can be used as force majeure by debtors, how to prove PSBB Covid-19 force majeure given the existence of an adage of feiten notoir, and the result of PSBB Covid-19 as a force majeure. To study it, normative juridical research is carried out using the statutory approach and conceptual approach to force majeure. The results show that Covid19 PSBB is not automatically attached to all debtors but must be personally proven to creditors. PSBB Covid-19 is a relative force majeure and results in the debtor's liability being recovered once again by the creditor.
\end{abstract}

Key words: Force Majeure, Proof, Effect, PSBB Covid-19

\begin{abstract}
ABSTRAK
Wabah Covid-19 sebagai pandemi yang menular secara cepat dan masif. Satusatunya cara memutus mata rantai penularan melalui pembatasan pergerakan orang. Pemerintah Indonesia memberlakukan kebijakan Pembatasan Sosial Berskala Besar dalam Peraturan Pemerintah No. 21 Tahun 2020 guna melindungi masyarakat. Di sisi lain pemberlakuan kebijakan PSBB Covid-19 justru menimbulkan kesulitan ekonomi bagi beberapa golongan masyarakat. Seperti perusahaan transportasi, pariwisata, hotel, restoran, pedagang harian dan lainnya. Tidak sedikit pula perusahaan yang melakukan PHK atau merumahkan karyawannya. Kesulitan ekonomi membawa akibat pelaksanaan perjanjian yang

\footnotetext{
${ }^{1}$ Dosen Tetap Fakultas Hukum Universitas Tama Jagakarsa, J1. TB. Simatupang No. 152 Tanjung Barat Jakarta Selatan, Email: sufiarina_01@yahoo.com

${ }^{2}$ Dosen Tetap Fakultas Hukum Universitas Bhayangkara Jakarta Raya, Jl. Raya Perjuangan, Marga Mulya, Bekasi Utara Kota Bekasi. Email: sri.wahyuniok17@yahoo.com
} 
sebelumnya telah berjalan lancar, tiba-tiba tidak dapat lagi dipenuhi karena debitor mengalami pengurangan atau bahkan kehilangan penghasilan. Berbagai kewajiban berdasarkan perjanjian tidak lagi dapat dipenuhi. Hukum memandang hal yang menyebabkan perjanjian tidak terpenuhi yaitu karena wanprestasi atau karena force majeure. Perlu dikaji apakah PSBB Covid-19 dapat dijadikan force majeure oleh debitor, bagaimaan pembuktian force majeure PSBB Covid-19 mengingat adanya adagium feiten notoir, serta akibat PSBB Covid-19 sebagai force majeure. Untuk mengkajinya dilakukan penelitian yuridis normatif dengan pendekatan peraturan perundang-undangan dan juga pendekatan konseptual terhadap force majeure. Hasil penelitian menunjukkan bahwa PSBB Covid-19 tidak melekat secara otomatis pada semua debitor tetapi harus dibuktikan secara personal kepada kreditor. PSBB Covid-19 merupaka force majeure yang relatif dan mengakibatkan suatu ketika kewajiban debitor kembali dapat ditagih kreditor.

Kata kunci: Force Majeure, Pembuktian, Akibat, PSBB Covid-19

\section{A. PENDAHULUAN}

World Health Organization (WHO) telah menyatakan Covid-19 sebagai Global Pandemic. ${ }^{3}$ Indonesiapun menjadi salah satu negara terdampak imbas virus corona (Covid-19). Kasus pertama menimpa dua warga Depok, Jawa Barat. ${ }^{4}$ Untuk penanganan Covid-19, Presiden Joko Widodo menyampaikan keterangan pers terkait penangangan COVID-19 di Istana Bogor. ${ }^{5}$ Presiden meminta agar masyarakat Indonesia, bekerja, belajar dan beribadah dari rumah serta tetap tenang, tidak panik, tetap produktif agar penyebaran COVID-19 ini bisa dihambat dan diberhentikan. Permintaan Presiden ini dalam tataran sebagai himbauan semata, namun telah ditindaklanjuti dengan baik oleh lingkungan pendidikan melalui program belajar dari rumah dan sebagian industri serta perusahaan dengan bekerja dari rumah.

Agar mempunyai kekuatan mengikat himbauan ini kemudian diperkuat dengan Peraturan Pemerintah No. 21 Tahun 2020 tentang Pembatasan Sosial Berskala Besar (PSBB), ${ }^{6}$ Dalam Rangka Percepatan Penanganan Corona Virus Disease 2019 (Covid-19). ${ }^{7}$ PP ini sebagai pelaksanaan Undang-Undang No 6 Tahun 2018 tentang Kekarantinaan Kesehatan. Pembatasan Sosial Berskala Besar paling sedikit meliputi:

a. peliburan sekolah dan tempat kerja;

\footnotetext{
${ }^{3}$ https://nationalgeographic.grid.id/read/132059249/who-tetapkan-covid-19-sebagai-pandemiglobal-apa-maksudnya, diakses 15 April 2020

${ }^{4}$ Diumumkan langsung Presiden Joko Widodo di Istana Kepresidenan, Jakarta, Senin (2/3/2020)", https://nasional.kompas.com/read/2020/03/03/06314981/fakta-lengkap-kasuspertama-virus-corona-di-indonesia?page=all diakses 15 April 2020

${ }^{5}$ Minggu (15/3/2020), https://www.kompas.com/sains/read/2020/03/16/200200923/kenapa-beradadi-rumah-bisa-selamatkan-hidup-dari-pandemi-covid-19. Diakses 17 April

${ }_{6}^{6}$ Pembatasan Sosial Berskala Besar (PSBB) adalah pembatasan kegiatan tertentu penduduk dalam suatu wilayah yang diduga terinfeksi penyakit dan/atau terkontaminasi sedemikian rupa untuk mencegah kemungkinan penyebaran penyakit atau kontaminasi. Perhatikan Pasal 1 angka (11) UU No 6 Tahun 2018 tentang Kekarantinaan Kesehatan.

${ }^{7}$ Ditetapkan tanggal 31 Maret 2020
} 
b. pembatasan kegiatan keagamaan; dan/atau

c. pembatasan kegiatan di tempat atau fasilitas umum.

Akibat dari pemberlakuan PSBB, banyak kegiatan bisnis tiba-tiba terhenti, para pedagang tidak lagi dirubung pembeli. Kegiatan bisnis baik individu atau keluarga, institusi maupun negara menjadi tidak dapat lagi melakukan kegiatan dan operasionalnya secara normal. Mall, restoran dan hotel tidak beroperasi, perdagangan sepi, dan tentu banyak usaha merugi. Tenaga marketing tidak dapat lagi memenuhi target penjualan, beberapa perusahaan menyikapi dengan melakukan pemutusan hubungan kerja. Atau para pekerja dirumahkan sementara yang mengakibatkan tidak lagi mempunyai penghasilan atau berkurangnya penghasilan.

Aktivasi usaha yang terhenti membuat pemasukan (cash flow) ke perusahaan tersendat. Padahal di sisi lain perusahaan masih harus membayar biaya operasional karyawan. Imbasnya beberapa perusahaan terpaksa melakukan PHK pada pekerja. Salah satunya PT. Indosat Tbk (ISAT) melakukan PHK terhadap 677 karyawan, yang dibenarkan Head Corporate Communications Indosat Ooredo. ${ }^{8}$ Pukulan pandemic Covid-19 merontokkan perekonomian masyarakat. Di beberapa wilayah seperti Pasar Tanah Abang, beberapa pemilik toko yang tidak patuh, oleh petugas dilakukan penutupan toko secara paksa. Mereka yang mendapatkan penghasilan secara harian, namun tiba-tiba terhenti, tentu membawa imbas kesulitan perekonomian. Akan berimbas pula bagi debitor yang punya kewajiban membayarkan sejumlah uang.

Pemerintah lebih lanjut menetapkan Keputuan Presiden (Kepres) No. 12 Tahun 2020 tentang Penetapan Bencana Nonalam Penyebaran Corona Virus Disease 2019 (Covid-19) sebagai Bencana Nasional, ${ }^{9}$ tertanggal 13 April 2020. Salah satu pertimbangannya bahwa bencana nonalam yang disebabkan oleh penyebaran Corona Virus Disease 2019 (Covid-19) telah berdampak meningkatnya jumlah korban dan kerugian harta benda, meluasnya cakupan wilayah yang terkena bencana, serta menimbulkan implikasi pada aspek sosial ekonomi yang luas.

Bagi debitor baik perorangan ataupun badan usaha di masa sebelum PSBB telah melaksanakan kontrak atau perjanjian dan dapat terlaksana dengan baik. Ada kemungkinan tiba-tiba terkendala dalam pemenuhan kewajiban disebabkan kebijakan PSBB imbas Covid-19. Kebijakan PSBB selalu disosialisasikan, dihimbau dan disampaikan kepada publik baik melalui himbauan petugas secara berkeliling, melalui televisi dan media lainnya. Dapat dikatakan kebijakan PSBB diketahui oleh setiap orang sebagai cara untuk menghambat dam memutus penularan wabah covid-19 yang juga menyebabkan beberapa pihak tidak dapat melaksanakan aktifitas ekonomi secara normal. Lagi pula kebijakan PSBB telah didasarkan pada peraturan perundang-undangan dalam bentuk peraturan pemerintah sehingga berlaku teori fiksi yang berarti setiap orang dianggap mengetahui.

Akibat pemberlakuan PSBB, banyak mall, tempat hiburan dan restoran ditutup, tidak beroperasi. PSBB berdampak secara ekonomi, beberapa perusahaan

\footnotetext{
${ }^{8}$ Sri Wahyuni, "Ketika pandemi virus corona jadi pertimbangan force majeure bencana nasional, begini analisanya", https://kaltim.tribunnews.com/2020/04/17/ketika-pandemi-virus-corona-jadipertimbangan-force-majeure-bencana-nasional-begini-analisanya, diakses 18 April 2020

${ }^{9}$ https://setkab.go.id/presiden-tetapkan-bencana-nonalam-penyebaran-covid-19-sebagai-bencananasional/ diakses 18 April 2020.
} 
mengamankan diri dengan melakukan pemutusan hubungan kerja (PHK) atau setidaknya merumahkan karyawan. Angkutan roda dua dan roda empat berbasis online atau konvensional dibatasi aktifitasnya. Pembatasan angkutan umum, berdampak pada penurunan atau kehilangan penghasilan bagi pengelola bus, berkurang atau hilangnya penghasilan bagi sopir khususnya angkutan umum. Sopir angkutan pariwisata gigit jari, karena tak ada lagi pelancong, mengakibatkan penghasilan mereka menurun bahkan hilang sama sekali. Bagi pihak-pihak tertentu situasi PSBB menjadikan penghasilan mereka hilang atau berkurang, namun tidak demikian halnya bagi Aparatur Sipil Negara, Anggota Tentara Republik Indonesia, anggota kepolisian dan mereka yang menerima penghasilan secara tetap tidak banyak membawa pengaruh, selain hanya pembatasan pergerakan fisik yang terbatas karena phisical distancing akibat PSBB.

Sangat besar kemungkinan pihak-pihak yang mengalami hambatan penghasilan, mempunyai kewajiban hukum berupa pembayaran sejumlah uang terhadap para kreditor yang telah berjalan sebelumnya secara tepat waktu. Tentu saja bagi mereka yang kondisi ekonomi atau penghasilannya terganggu dengan adanya situasi PSBB menjadikan para debitor tiba-tiba terhalang untuk memenuhi kewajibannya secara tepat waktu pada kreditor.

Halangan atau kegagalan berprestasi menyebabkan debitur wanprestasi dan memberikan hak gugat kepada kreditur untuk menegakkan hak-hak kontraktualnya seperti menerima ganti rugi dari debitur. Namun demikian, hukum juga memberikan hak kepada debitur untuk memberikan pembelaan. Pembelaan debitur dilakukan dengan cara mengajukan tangkisan bahwa tidak terlaksananya prestasi karena adanya keadaan memaksa (force majeure). ${ }^{10}$

Dengan demikian perlu dicari tahu, apakah para debitor dapat menggunakan PSBB Covid-19 sebagai force majeure? Apakah PSBB Covid-19 berlaku sebagai Feiten Notoir bagi debitor untuk menyatakan force majeure? Bagaimana akibat force majeure kebijakan PSBB Covid-19?

Untuk menemukan jawabannya, dilakukan penelitian yuridis normatif. Penelitian dengan pendekatan peraturan perundang-undangan ${ }^{11}$ khususnya atas Pasal 1244, 1245 KUHPerdata, dikaitkan dengan pengaturan dan akibat PSBB Covid-19. Didalami pula dengan pendekatan konseptual atas force majeure, yaitu menggunakan pandangan-pandangan dan doktrin-doktrin yang berkembang. ${ }^{12}$

\section{B. PEMBAHASAN}

\section{Penggunaan PSBB Covid-19 oleh Debitor sebagai Force Majeure}

Prinsipnya kewajiban untuk melaksanakan isi perjanjian adalah mutlak. ${ }^{13}$ Perjanjian yang dibuat oleh para pihak menimbulkan perikatan. Perikatan sebagai

\footnotetext{
${ }^{10}$ Joni Emirzon, Fungsi Klausula Force Majeure Dalam Hukum Kontrak Antara Teori Dan Praktik, Paper dalam Seminar Online (Webinar) yang diselenggarakan oleh Asosiasi Pengajar Hukum Keperdataan Bekerja Sama dengan Universitas Narotama Surabaya, Rabu, 22 April 2020 pukul 14.00 Sd 18.00.

${ }^{11}$ Peter Mahmud Marzuki, Penelitian Hukum, (Jakarta, Kencana Prenada Media Grup, Cetakan ke3, 2007) hal 93

${ }^{12}$ Ibid, hlm 94.

${ }^{13}$ S.B. Marsh and J. Solsby, Business Law, Alih Bahasa Abdulkadir Muhammad, Hukum Perjanjian, (Bandung, Alumni, 2006) hal 171
} 
hubungan hukum menimbulkan hak dan kewajiban yang harus dipenuhi para pihak. Pihak yang dibebani kewajiban dalam hukum disebut debitor, sedangkan pihak yang berhak menuntut disebut kreditor. Bila debitor tidak melaksanakan atau tidak memenuhi kewajiban sebagaimana telah disanggupi semula, hukum menentukan debitor ada dalam keadaan wanprestasi. Dalam hal pemenuhan prestasi telah ditentukan tanggal pelaksanaan dari semula, sangatlah mudah menentukan debitor wanprestasi, yaitu dengan telah lewatnya tanggal yang disepakati sedangkan debitor tetap tidak berprestasi.

Salah satu hal yang oleh Kitab Undang-Undang Hukum Perdata (KUHPerdt) dinilai memiliki makna yang sangat penting dalam menentukan ada tidaknya wanprestasi adalah mengenai pelaksanaan perikatan pada waktunya. Untuk keperluan menentukan kapan debitor telah wanprestasi, terwujud dalam bentuk ketiada-laksanaan perikatan pada waktunya. ${ }^{14}$

Tidak terpenuhinya perjanjian dapat dikarenakan 2 (dua) hal yaitu wanprestasi dan force majeure. Baik wanprestasi maupun force majeure mengakibatkan perjanjian tidak terlaksana sebagaimana mestinya. Dengan demikian wanprestasi dan force majeure sama-sama berada dalam tahapan pelaksanaan perjanjian. Lebih tepatnya keberadaan wanprestasi atau force majeure ada pada perjanjian yang tidak terlaksana. Sedangkan perbedaan antara wanprestasi dan force majeure terletak pada keberadaan unsur kelalaian (kesalahan) pada debitor. Wanprestasi mensyaratkan adanya unsur kesalahan atau kelalaian pada debitor. Sebaliknya pada force majeure unsur kesalahan atau kelalaian justru tidak berada pada debitor. Perbedaan lainnya antara wanprestasi dan force majeure terkait dengan beban pembuktian. Beban pembuktian pada wanprestasi berada di tangan kreditor, sedangkan beban pembuktian pada force majeure ada pada si debitor. ${ }^{15}$ Lebih jauh wanprestasi dan force majeure mempunyai akibat hukum yang berbeda bagi debitor. Perbedaan akibat wanprestasi dan force majeure didasarkan pada Pasal 1244 KUHPerdata yang berbunyi;

"Jika ada alasan untuk itu, debitor harus dihukum mengganti biaya, rugi dan bunga apabila ia tak dapat membuktikan, bahwa hal tidak atau tidak pada waktu yang tepat dilaksanakannya perikatan itu, disebabkan suatu hal yang tak terduga, pun tak dapat dipertanggungjawabkan padanya, kesemuanya itupun jika itikad buruk tidaklah ada padanya."

Jika diperhatikan lebih lanjut ketentuan Pasal 1244 KUHPerd memuat dua norma berikut:

a. Norma yang pertama dengan muatan, yaitu "Jika ada alasan untuk itu, debitor harus dihukum mengganti biaya, rugi dan bunga". Artinya bila pada debitor ditemukan alasan kesalahan atau kelalaian (wanprestasi) maka debitor dapat dibebankan untuk mengganti biaya rugi dan bunga. Debitor yang tidak berprestasi atau berprestasi tidak pada waktu yang tepat (wanprestasi) dihukum untuk mengganti biaya rugi dan bunga;

b. Norma yang kedua dengan muatan, "tak dapat dipertanggungjawabkan pada debitor, apabila ia dapat membuktikan tidak terlaksana atau tidak pada waktu yang tepat pemenuhan prestasi disebabkan hal yang tak

\footnotetext{
${ }^{14}$ Kartini Mulyadi \& Gunawan Widjaja, Perikatan Pada Umumnya, Cetakan Kedua, (Jakarta, Raja Grafindo Persada, 2004) hlm 57

${ }^{15}$ Perhatikan Pasal 1244 KUHPerdata
} 
terduga dan itikad buruk tidak ada padanya, tidaklah dibebani untuk mengganti biaya rugi dan bunga."

Selain Pasal 1244 KUHPerd, juga ditemukan pengaturan force majeure dalam Pasal 1245 KUHPerd yang menentukan, "Tidaklah biaya rugi dan bunga harus digantinya, apabila lantaran keadaan memaksa atau lantaran suatu kejadian tak disengaja si berutang berhalangan memberikan atau berbuat sesuatu yang diwajibkan, atau lantaran hal-hal yang sama telah melakukan pelanggaran." Muatan Pasal 1245 KUHPerd, memperkuat kedudukan debitor yang mengalami force majeure, jika keadaan memaksa menyebabkan debitor berhalangan memenuhi prestasi atau telah melakukan pelanggaran maka tidaklah mengganti biaya rugi dan bunga.

Menurut Riduan Syahrani;"16 "Biaya, rugi dan bunga yang timbul akibat wanprestasi maupun force majeure disebut dengan risiko." Risiko dalam perjanjian ialah kewajiban memikul kerugian terhadap suatu kejadian di luar kesalahan salah satu pihak. ${ }^{17}$ Beban menanggung risiko inilah yang berbeda pada wanprestasi dan force majeure. Berarti dengan adanya unsur kesalahan atau kelalaian debitor sehingga terjadi wanprestasi, maka risiko yang muncul akibat waprestasi menjadi beban dari debitor untuk menggantinya. Namun dengan force majeure berarti prestasi tidak terlaksana tanpa adanya kesalahan atau kelalaian debitor tapi karena adanya peristiwa tak terduga sedangkan itikat buruk tidak ada padanya maka debitor dibebaskan dari menanggung risiko.

Force majeure bersinonim dengan overmacht, keadaan memaksa dan sering juga disebut sebab kahar. Menurut Salim HS, ${ }^{18}$ keadaan memaksa adalah suatu keadaan dimana debitor tidak dapat melakukan prestasinya pada kreditor, yang disebabkan adanya kejadian yang berada di luar kekuasaannya, seperti karena adanya gempa bumi, banjir, lahar dan lain-lain. Sejalan dengan yang disampaikan R. Setiawan;" "Keadaan memaksa adalah suatu keadaan yang terjadi setelah dibuatnya perjanjian, yang menghalangi debitor untuk memenuhi prestasinya, dimana debitor tidak dapat dipersalahkan dan tidak harus menanggung risiko serta tidak dapat menduga pada waktu perjanjian dibuat." Dapat dinyatakan bahwa force majeure sebagai perjanjian tidak dapat terlaksana karena adanya peristiwa tak terduga yang terjadi di luar tanggung jawab debitor, sehingga debitor tidak perlu menanggung risiko.

Menurut M. Isnaeni ${ }^{20}$ beban pembuktian force majeure ada pada debitor. Debitor dibebani pembuktian untuk meyakinkan kreditor bahwa tidak berprestasinya debitor dikarenakan;

a. Terjadinya peristiwa tak terduga, tidak disangka peristiwa tertentu akan terjadi;

b. Peristiwa yang terjadi muncul di luar kesalahannya;

c. Peristiwa yang terjadi menghalangi debitor dalam pemenuhan prestasi.

\footnotetext{
${ }^{16}$ Riduan Syahrani, Seluk Beluk dan Asas-Asas Hukum Perdata, (andung, Alumni, 2004) hal 238

${ }^{17}$ C.S.T. Kansil, Modul Hukum Perdata Termasuk Asas-Asas Hukum Perdata, (Jakarta, Pradnya Paramita, 1995) hal 228

${ }^{18}$ Salim HS, Pengantar Hukum Perdata Tertulis, (Jakarta, Sinar Grafika, 2005) hal 183

19 Sebagaimana dikutip F.X. Suhardana, Contract Drafting, Kerangka Dasar dan Teknik Penyusunan Kontrak, Edisi Revisi, (Y ogyakarta,Universitas Atma Jaya, 2009), hal 56

${ }^{20}$ M. Isnaeni, Filosofi Pengaturan Force Majeure Dalam Hukum Perikatan, Paper dalam Seminar Online (Webinar) yang diselenggarakan oleh Asosiasi Pengajar Hukum Keperdataan Bekerja Sama dengan Universitas Narotama Surabaya, Rabu, 22 April 2020 pukul 14.00 sd 18.00.
} 
Ketiga hal di atas harus dibuktikan debitor, agar memenuhi syarat force majeure yang bersifat akumulasi. Ketiga syarat yang ditentukan harus ada secara sekaligus dan bersamaan. Bila debitor dapat membuktikan ketiga syarat tersebut, maka debitor tak bertanggung gugat atas risiko yang terjadi. Hal ini sesuai dengan Mariam Darus Badrulzaman, ${ }^{21}$ yang menyatakan; "pembentuk undang-undang menginginkan bahwa force majeure itu sebagai alasan pembenar untuk membebaskan debitor dari kewajiban mengganti rugi."

Sehubungan kebijakan PSBB sebagai penanganan dan pencegahan penularan Covid-19 di Indonesia, yang membawa akibat penurunan aktifitas ekonomi bagi debitor tertentu. Dimaksud debitor tertentu adalah debitor yang perolehan penghasilan ekonominya menjadi terganggu, menurun atau hilang dengan pemberlakuan aturan kebijakan PSBB Covid-19. Karena debitor tak bisa lagi melakukan aktifitas ekonominya, seperti usaha transpotrasi, pariwisata, perhotelan dan mall, yang mempekerjakan banyak orang. Debitor yang terkena imbas, sehingga terkendala dalam pemenuhan kewajiban disebabkan berlakunya kebijakan PSBB Covid-19 dapat mengemukakan keadaan kendala baginya dalam pemenuhan kewajibannya. Debitor tertentu harus berupaya meyakinkan kreditor akan keterbatasan yang ada padanya secara personal. Sedangkan bagi debitor yang berprofesi sebagai Aparatur Sipil Negara, anggota Tentara Nasional Indonesia maupun anggota Kepolisian dan debitor lainnya yang penghasilan atau keadaan ekonominya tidak terganggu (golongan mampu) dengan adanya ketentuan PSBB Covid-19 tidaklah dapat dan tidak layak menggunakan situasi PSBB Covid-19 sebagai force majeure. Karena mereka tetap menerima penghasilan secara rutin sebagaimana penghasilan sebelum berlakunya ketentuan PSBB Covid-19.

Kondisi PSBB dalam suasana musibah Covid-19, adalah suatu keadaan yang tidak terduga sebelumnya. Tidak terbayangkan akan terjadi oleh para pihak yang mengadakan perjanjian. Hanya bagi debitor tertentu saja yang mengalami masalah keuangan. Sedangkan bagi debitor yang mempunyai penghasilan tetap seperti Aparatur Sipil Negara (ASN), anggota Tentara Nasional Indonesia, anggota kepolisian, dan mereka yang mempunyai penghasilan tetap lainnya, atau debitor yang mampu, kendala ekonomi tidaklah dirasakan. Dengan demikian melekatnya force majeure akibat kebijakan PSBB Covid-19, tidaklah secara otomatis dan tidak melekat untuk semua debitor. Force majeure akibat PSBB Covid-19 hanyalah berlaku bagi debitor yang terkendala secara langsung dalam pemenuhan kewajiban karena penghasilannya menjadi berkurang atau lenyap.

Debitor tertentu baik individual maupun korporate harus mengemukakan keadaan keterbatasan dan kendalanya secara personal dalam memenuhi kewajiban akibat situasi PSBB Covid-19. Sedangkan bagi debitur yang mempunyai penghasilan tetap dan rutin atau berada dalam keadaan mampu, maka kondisi PSBB Covid-19 tidak dapat dikategorikan ada force majeure baginya. Dengan demikian keberadaan situasi PSBB Covid-19 sebagai force majeure, tidaklah berlaku secara otomatis bagi semua debitor. Hanya debitor tertentu saja yang dapat menggunakan situasi pemberlakuan PSBB Covid-19 sebagai force majeure.

\section{Pembuktian force majeure oleh debitor dalam situasi PSBB Covid-19}

\footnotetext{
${ }^{21}$ Mariam Darus Badrulzaman, et all, Kompilasi Hukum Perikatan, (Bandung, Cita Aditya Bakti, 2001), hal 25
} 
Pembuktian hanya diperlukan dalam hal adanya sengketa, konflik atau adanya ketidaksesuaian. Pembuktian diperlukan ketika ada permasalahan yang harus diselesaikan. Menurut Nur Rasaid membuktikan ialah meyakinkan hakim tentang kebenaran dalil-dalil yang dikemukakan dalam suatu persengketaan. ${ }^{22}$ Meskipun demikian tidaklah semua sengketa bermuara di Pengadilan. Mengingat pengadilan hanyalah merupakan pintu terakhir dalam penyelesaian sengketa (ultimum remedium).

Subekti $^{23}$ menyatakan force majeure harus dibuktikan oleh debitor, sedangkan siapa yang menuntut penggantian kerugian yang disebabkan suatu perbuatan melangar hukum harus membuktikan adanya kesalahan pihak yang dituntut. Adanya force majeure bagi debitor dalam pemenuhan prestasi, haruslah dibuktikan oleh debitor pada kreditor. Debitor harus mampu meyakinkan kreditor bahwa sungguh-sungguh berada dalam kesulitan ekonomi akibat pemberlakuan kebijakan PSBB Covid-19. Debitor tidak cukup menyatakan PSBB Covid sebagai force majeure, namun harus mampu membuktikan secara personal keadaan kendala yang dihadapinya sehingga tidak dapat memenuhi prestasi sebagaimana mestinya. Pembuktian untuk mengungkapkan fakta yang mengandung kebenaran yang diterima akal sehat (common sense), ${ }^{24}$ artinya kebenaran fakta yang dikemukakan selaras dengan kebenaran menurut kesadaran masyarakat.

Mengingat pada pembuktian di pengadilan dikenal adanya adagium fakta notoir (notoire feiten) ${ }^{25}$, yaitu sesuatu yang tidak perlu dibuktikan lagi karena fakta tersebut telah diketahui secara umum. Keberadaan covid 19 dan imbas PSBB termasuk pada kondisi notoir feiten, semua orang mengetahui. Apalagi kebijakan PSBB berdasarkan pada Peraturan Pemerintah No. 21 Tahun 2020 tentang Pembatasan Sosial Berskala Besar Dalam Rangka Percepatan Penanganan Corona Virus Disease 2019 (Covid-19). Dalam pemberlakuan peraturan perundangundangan berlakukan teori fiksi yaitu semua orang dianggap mengetahuinya. Teori ini berguna untuk memberikan kepastian hukum.

PSBB Covid-19 diketahui oleh semua orang, namun dalam meyakinkan kreditor, pihak debitor justru harus membuktian kondisi PSBB Covid-19 menjadikannya terkendala secara personal memenuhi prestasi sehingga debitor berada dalam keadaan force majeure. Keberadaan notoir feiten atas imbas PSBB tidaklah berlaku secara otomatis bagi semua debitor, hanya bagi debitor tertentu yang mengalami kendala secara personal dan harus membuktikan kendala tersebut agar dilepaskan dari keadaan wanprestasi. Untuk dapat menggunakan PSBB Covid19 sebagai force majeure, justru debitor harus membuktikan dan menyakinkan kreditor bahwa fakta PSBB Covid-19 membuatnya berada dalam keadaan tidak mampu untuk memenuhi prestasi.

Debitor sangat perlu mengemukakan dan membuktikan force majeure baginya, sehingga timbul kendala bagi debitor dalam pemenuhan kewajibannya dan meyakinkan kreditor dengan pembuktian yang dapat diterima kreditor. Artinya

\footnotetext{
${ }^{22}$ Nur Rasaid, Hukum Acara Perdata, (Jakarta, Sinar Grafika, 1995), hal 36

${ }^{23}$ Subekti, Hukum Pembuktian, (Jakarta, Pradnya Paramita), hal 19

${ }^{24}$ M. Yahya Harahap, Hukum Acara Perdata, tentang Gugatan Persidangan, Penyitaan, Pembuktin dan Putusan Pengadilan. (Jakarta, Sinar Grafika, 2008) hal 508,

${ }^{25}$ Retnowulan Sutantio dan Iskandar Oeripkartawinata, Hukum Acara Perdata dalam Teori dan Praktek, (Bandung, Mandar Maju 2002), hal 58. Perhatikan pula M. Yahya Harahap, Hukum Acara Perdata, tentang Gugatan Persidangan, Penyitaan, Pembuktian dan Putusan Pengadilan. (Jakarta, Sinar Grafika, 2008), hal 508,
} 
dalam hal ini tidaklah berlaku adagium notoir feiten sebagai prinsip dalam pembuktian bahwa sesuatu yang diketahui oleh umum tidak perlu dibuktikan lagi. Meskipun ketentuan PSBB Covid-19 diketahui oleh semua orang, namun debitor yang terkendala dalam pemenuhan kewajibannya akibat pemberlakuan PSBB Covid-19 harus membuktikannya pada kreditor.

Dalam kondisi pemberlakuan PSBB di masa Covid-19 risiko dapat diartikan jika kreditornya rugi, maka kerugian kreditor tidak dapat dibebankan pada debitor, dengan persyaratan debitor yang membuktikan adanya keadaan memaksa. Artinya keadaan PSBB Covid-19 selaku fakta yang tidak terbantahkan memang telah terjadi, namun tidaklah secara otomatis menjadikan debitor berada dalam force majeure. Debitor tetap tetap harus membuktikan secara personal ada kendala padanya dalam pemenuhan perikatan akibat kebijakan PSBB Covid-19. Secara lebih jauh dapat dikatakan adanya perbedaan pembuktian notoir feiten dalam penyelesaian sengketa perdata di pengadilan dengan pembuktian force majeure yang bersifat relatif.

\section{Akibat Force Majeure karena Kebijakan PSBB Covid-19}

Pemerintah memberlakukan PSBB sebagai bentuk perlindungan terhadap kesehatan masyarakat dari penyakit menular. Penularan Covid-19 berpotensi menimbulkan kedaruratan kesehatan masyarakat. Pemberlakuan Pembatasan Sosial Berskala Besar (PSBB) merupakan bagian dari respon pemerintah, atas kedaruratan kesehatan masyarakat yang harus dilindungi. PSBB bertujuan mencegah meluasnya penyebaran penyakit yang mengancam kedaruratan kesehatan masyarakat yang sedang terjadi antar orang di suatu wilayah tertentu, ${ }^{26}$ dan saat ini covid-19 merupakan wabah yang sudah bersifat pandemik.

Pemberlakuan PSBB dalam rangka mengatasi pandemi Covid-19, sebagai keadaan yang tak terbayangkan dan tak dapat diduga akan terjadi. Begitu pula debitor tak dapat menduga tiba-tiba tak bisa lagi memenuhi kewajibannya pada kreditor. Force majeure yang menimpa debitor haruslah terjadi setelah perikatan dibuat, ${ }^{27}$ dan sebelum debitor dinyatakan lalai. Bila saat membuat perikatan, debitor ternyata menyadari adanya kemungkinan terjadi force majeure, tentunya debitor tak dapat dilepaskan dari risiko.

Ternyata pemberlakuan kebijakan PSBB, menimbulkan keterpurukan ekonomi bagi sebagian besar masyarakat. Banyak masyarakat tak bisa lagi berusaha secara ekonomi, sehingga kondisi ekonominya menjadi berkurang dan merosot dan bahkan dapat disebut terpuruk. Dari sisi hukum perjanjian, pemberlakuan PSBB ini dapat dikategorikan sebagai hal tak terduga yang tak disangka sebelumnya. Bagi debitor tertentu yang punya kewajiban membayarkan sejumlah uang, besar kemungkinan mengalami kendala dalam pemenuhan kewajiannya. Dengan landasan karena kebijakan PSBB yang menimbulkan imbas, debitor terkendala dalam pemenuhan kewajiban pembayaran sejumlah uang, maka debitor tersebut tidak dapat dikatakan wanprestasi dan risiko dari terhalangnya memenuhi kewajiban tidaklah dapat dibebankan pada debitor.

Salah satu syarat force majeure yaitu kendala terjadi sebelum debitor dinyatakan lalai atau wanprestasi. Apabila sebelum berlakunya kebijakan PSBB

\footnotetext{
${ }^{26}$ Perhatikan Pasal 59 UU No. 16 Tahun 2018 tentang Kekarantinaan Kesehatan

${ }^{27}$ R.M. Suryodiningrat, Azas-Azas Hukum Perikatan, (Bandung, Tarsito, 1995), hal 37
} 
Covid-19, debitor sudah lebih dahulu wanprestasi, dan tetap berlanjut wanprestasinya, maka kebijakan PSBB Covid-19 tidaklah dapat dijadikan daasr force majeure baginya. Debitor tetap berada dalam keadaan wanprestasi dan risiko beralih menjadi tanggungan debitor, karena adanya unsur kesalahan atau kelalaian pada debitor. Force majeure hanya dapat diberlakukan bagi debitor tertentu yang kewajibannya telah berjalan baik sebelum adanya pemberlakuan PSBB Covid-19. Justru dengan berlakunya PSBB Covid-19, membawa akibat debitor terhalang dalam pemenuhan kewajibannya pada kreditor, sebelum debitor dinyatakan lalai.

Seperti dipahami bahwa force majeure hanya ada dalam tataran pelaksanaan perjanjian. Yaitu perjanjian yang justru tidak terlaksana karena adanya hal atau peristiwa tak terduga yang menyebabkan debitor terhalang dalam memenuhi kewajibannya. Lain halnya dalam perjanjian bertimbal balik, bila para pihak dari semula sama-sama belum memenuhi kewajibannya, maka tidak dapatlah dibicarakan force majeure. Bila para pihak sama-sama belum menunaikan kewajibannya justru penyelesaiannya tidaklah sulit, dan masing-masing pihak bisa menangkis tuduhan wanprestasi dengan mengajukan Exceptio Non Ademplati Contractus. ${ }^{28}$ Maksudnya karena pihak yang satu tidak berprestasi, maka pihak lain juga tidak perlu berprestasi.

Force majeure membawa konsekuensi perjanjian tidak dapat terlaksana dan debitor tidak dapat dituntut supaya berprestasi. Force majeure membawa akibat hukum sebagai berikut ${ }^{29}$

a. Debitor tidak dapat dinyatakan lalai (wanprestasi);

b. Kreditor tidak dapat minta pemenuhan prestasi pada debitor:

c. Risiko tidak beralih kepada debitor.

KUHPerdata mengatur akibat force majeure dalam Pasal 1444 dan 1445 yang menentukan objek perjanjian musnah, maka perikatan menjadi hapus. Namun dalam hal prestasi debitor berupa kewajiban membayar sejumlah uang, tidaklah tepat menjadikan ketentuan Pasal 1444 dan 1445 KUHPerdata sebagai langkah penyelesaian force majeure. Sebagaimana disampaikan Scholten yang dirujuk oleh J. Satrio ${ }^{30}$; "Menuntut pembebasan diri dari kewajiban membayar sejumlah uang atas dasar force majeure tidak dibenarkan."

Menurut Agus Yudha Hernoko, ${ }^{31}$ perlu diperhatikan sifat force majeure terhadap kemungkinan pelaksanaan prestasi, yaitu"

a. Force majeure yang bersifat tetap atau permanen, yang mengakibatkan pelaksanaan prestasi tidak mungkin dilakukan.

b. Force majeure yang bersifat tidak tetap atau temporer, yang mengakibatkan pelaksanaan prestasi secara normal tidak mungkin dilakukan, namun secara tidak normal mungkin dilakukan atau untuk sementara waktu ditangguhkan sampai dimungkinkannya pemenuhan prestasi kembali.

\footnotetext{
${ }^{28}$ Riduan Syahrani, Seluk Beluk dan Asas-Asas Hukum Perdata, (Bandung, Alumni, 2008), hal 241.

${ }^{29}$ F.X. Suhardana, Contract Drafting, Kerangka Dasar dan Teknik Penyusunan Kontrak, Edisi Revisi, (Yogyakarta, Universitas Atma Jaya, 2009), hal 57

${ }^{30}$ J. Satrio, Hukum Perikatan-Perikatan Pada Umumnya, Cetakan Ketiga, (Bandung, Alumni, 1999) hal, 259 sebagaimana dikutipnya dari P. Scholten, Resiko en Shuld bij contractueele verhoudinmgen, hal 255.

${ }^{31}$ Agus Yudha Hernoko, Hukum Perjanjian, Asas Proporsional dalam Kontrak Komersial, cetakan keempat (Jakarta, Prenada Media Grup, 2014) hal 273
} 
Akibat pemberlakuan kebijakan PSBB Covid-19, dalam hal debitor dapat membuktikan timbul kendala baginya dalam pemenuhan kewajibannya. Maka kebijakan PSBB Covid-19 dapat diberlakukan sebagai force majeure baginya. Maka debitor tidaklah menanggung risiko atas tidak terpenuhi kewajibannya. Sesuai dengan yang disampaikan Agus Yudha Hernoko, maka debitor dibebaskan dari menanggung risiko yang timbul karena terhalangnya pemenuhan perjanjian. Kewajiban debitor tetap melekat, hanya saja akan menjadi tertunda dalam pemenuhannya. Pembuktian adanya force majeure oleh debitor, hanya membebaskan debitor dari menanggung risiko atas tidak terlaksananya perjanjian. Yaitu bebas dari menanggung biaya, rugi dan bunga karena keterlambatan. Sedangkan kewajiban yang ditentukan dalam perjanjian tetap melekat pada debitor, hanya tertunda dalam pemenuhannya.

Berarti force majeure tidaklah menghapuskan kewajiban debitor. Dengan adanya force majeure, debitor dapat mengajukan peninjauan atau minta penanganan atas kewajibannya kepada debitor seperti melalui restrukturisasi, berupa rescheduling, atau reconditioning resctruturing. ${ }^{32}$ Beruntung pula pemerintah melalui kebijakan seperti Peraturan Otoritas Jasa Keuangan (POJK), turut ambil peduli dengan kenyataan yang ada di masyarakat. Secara hukum sesungguhnya perjanjian adalah murni urusan privat, urusan perseorangan. Tidaklah diperlukan campur tangan negara dalam urusan perjanjian seseorang dengan pihak lainnya yang bersifat privat. Namun dalam suasana PSBB Covid-19 adalah lebih bijaksana adanya campur tangan negara dengan menerbitkan POJK sebagai langkah negara dalam melindungi banyaknya masyarakat menjadi lebih lemah secara ekonomi, imbas kebijakan PSBB Covid-19. Melalui aturan PJOK No. 11/POJK.03/2020 tentang Stimulus Perekonomian Nasional Sebagai Kebijakan Countercyclical Dampak Penyebaran Coronavirus Disease 2019. Membuktikan keberadaan negara dalam melindungi warga khususnya yang terdampak oleh ketentuan PSBB Covid-19. Kebijakan POJK juga memberikan kepastian hukum kepada para kreditor dengan memberikan perlakuan khusus terhadap kredit atau pembiayaan yang diberikan restrukturisasi kepada debitor yang terkena dampak ekonomi atas pemberlakuan kebijakan PSBB Covid-19.

Penerapan kebijakan mendukung stimulus pertumbuhan ekonomi untuk debitor tertentu berlaku sampai dengan 31 Maret 2021. ${ }^{33}$ Berlandaskan pada Peraturan Otoritas Jasa Keuangan No. 11/POJK.03/2020, debitor dapat meminta negosiasi ulang kepada kreditor dengan cara minta penangguhan atau penundaan. Dengan demikian keadaan memaksa tidaklah menghapuskan kewajiban, tetapi hanya dalam rangka penunda sampai keadaan memaksa itu menjadi lenyap. Pemerintah berupaya memberikan keringanan berupa penundaan pembayaran cicilan kredit selama enam bulan. Keringanan ini mengacu pada Peraturan Pemerintah Pengganti UU (Perppu) nomor 1 tahun 2020 tentang Keuangan Negara dan Stabilitas Sistem Keuangan untuk Penanganan Pandemi Covid-19. ${ }^{34}$ Program pemerintah dengan memberlakukan keringanan berupa penundaan pembayaran cicilan sangat membantu ekonomi masyarakat dan

\footnotetext{
${ }^{32}$ Dewi Nurul Musjtari, Regulasi Restruturisasi Pembiayaan Bermasalah Pada Perbankan Syariah, Paper pada webinar APPHEISI, Senin 20 April 2020 jam 14.00 sd 17.00

${ }^{33}$ Perhatikan Pasal 10 POJK No. 11/POJK.03/2020.

$34 \quad$ https://republika.co.id/berita/q96qs2370/penundaan-cicilan-segera-berlaku-ini-penjelasanmenkeu, diakses 17 April 2020.
} 
kepastian hukum bagi debitor dan kreditor serta dunia usaha pada umumnya. Kebijakan pemerintah dan POJK telah memperkuat terjadinya keadaan force majeure bagi debitor tertentu sehingga debitor tidak perlu menanggung risiko.

Sejalan dengan kebijakan pemerintah yang memberikan keringan bagi debitor dalam pemenuhan prestasi berupa penundaan. Berarti Force majeure akibat kebijakan PSBB-Covid-19 bersifat relatif, ${ }^{35}$ karena hanya bersifat sementara. Bagi debitor yang telah membuktikan dirinya berada dalam keadaan force majeure dalam pemenuhan prestasi, tentu saja berhak mengajukan negosiasi untuk mendapatkan penundaan pemenuhan prestasi pada kreditor. Force majeure relatif menurut Vollmar dasarnya ialah kesulitan debitor memenuhi prestasi, karena ada peristiwa yang menghalangi debitor untuk berprestasi. ${ }^{36}$

Jika penyebaran dan penularan Covid-19 sudah dapat diakhiri, maka suatu ketika keadaan PSBB tentu akan berakhir pula. Dapat dinyatakan bahwa keadaan force majeur bagi debitor tertentu juga menjadi berakhir. Setidaknya dengan mendasarkan pada POJK No. 11/POJK.03/2020 sampai tanggal 31 Maret 2021. Begitu keadaan force majeure berakhir, kewajiban debitor dapat dilaksanakan kembali. Karena force majeure akibat kebijakan PSBB Covid-19 hanyalah bersifat relatif.

Setelah berakhirnya force majeure perikatan kembali aktif dan debitor mulai kembali dibebani dengan memenuhi kewajibannya. Setelah penundaan dan keringanan di masa force majeure kreditor dapat lagi meminta debitor untuk memenuhi prestasinya (sesuai restrukturisasi). Berakhirnya PSBB Covid-19 perjanjian yang tadinya terhenti sementara oleh force majeure, menjadi aktif dan berlanjut kembali. Namun ada kemungkinan keadaan dan kekuatan financial debitor belum tentu dapat pulih sebagaimana halnya sebelum pemberlakuan PSBB Covid-19. Jika dengan kelanjutan perjanjian debitor tetap tidak mampu untuk memenuhi kewajiban yang sudah disepakati semula, maka dalam hal demikian berlaku schuld dan haftung. Dalam perikatan terdapat unsur schuld dan haftung. Schuld adalah kewajiban debitor untuk berprestasi. ${ }^{37}$ Dan haftung sebagai kewajiban debitor untuk menjamin pemenuhan prestasi dengan seluruh kekayaannya. ${ }^{38}$

\section{KESIMPULAN DAN SARAN}

1. Kesimpulan

a. Penggunaan kebijakan PSBB Covid-19 sebagai force majeure tidaklah melekat secara serta merta kepada semua debitor. Hanya dimungkinkan bagi debitor tertentu yang betul-betul terkendala secara finansial dalam memenuhi kewajibannya yang bernilai uang. Debitor yang mengalami gangguan penghasilan sebagai akibat PSBB Covid-19, seperti pekerja yang di PHK, debitor yang menjalankan usaha transportasi, pariwisata,

\footnotetext{
${ }^{35}$ Force majeure yang relatif bersifat sementara, perhatikan Djaja S Meliala, Perkembangan Hukum Perdata Tentang Benda dan Hukum Perikatan, Cetakan Kedua, (Bandung, Nuansa Aulia,2008), hal 103. Perhatikan pula Riduan Syahrani, Seluk Beluk dan Asas-Asas Hukum Perdata, (Bandung, Alumni, 2008), hal 237.

${ }^{36}$ Abdulkadir Muhammad, Hukum Perdata Indonesia, (Bandung, Citra Aditya Bakti, 2000), hal 206.

${ }^{37}$ Munir Fuady, Hukum Kontrak dari Sudut Pandang Hukum Bisnis, (Bandung, Citra Aditya Bakti, 2001) hal 25

${ }^{38}$ Ibid.
} 
restoran maupun perhotelan dan debitor pelaku usaha harian. Sedangkan bagi debitor yang memperoleh penghasilan tetap dan rutin seperti Aparatur Sipil Negara, anggota Tentara Nasional Indonesia, anggota Kepolisian atau debitor yang mempunyai penghasilan lain secara rutin atau debitor mampu, tidak dapat menjadikan PSBB Covid-19 sebagai force majeure.

b. Kebijakan PSBB Covid-19 merupakan fakta yang tidak terbantahkan, bahkan berdasarkan pada produk peraturan perundang-undangan berupa Peraturan Pemerintah yang pemberlakuannya menggunakan teori fiksi, semua orang dianggap mengetahui. Namun pembuktian kebijakan PSBB Covid-19 sebagi force majeure, tidaklah berlaku adagium feiten notoir. Debitor haruslah mengemukakan dan membuktikan secara personal yang mungkin saja berbeda yang dialaminya dengan yang dialami oleh debitor lainnya. Pembuktian personal dengan menyakinkan kreditor bahwa kebijakan PSBB Covid-19 membawa imbas kesulitan keuangan secara langsung baginya, sehingga tak bisa dituntut atas risiko dan pemenuhan kewajibannya.

c. Dengan PSBB Covid-19 sebagai force majeure, mengakibatkan debitor tidak dapat dikatakan wanprestasi dan tidak menanggung biaya, rugi dan bunga. Beban perjanjian tetap menjadi kewajiban debitor. Debitor dapat mengajukan keringanan dengan cara menawarkan negosiasi dan dengan menggunakan dasar pada POJK No.11/POJK.03/2020. PSBB Covid-19 merupakan Force majeure yang bersifat relatif sehingga tidaklah menghapuskan kewajiban debitor. Dengan berakhirnya PSBB-Covid berakhir pula force majeure dan kewajiban debitor kembali dapat ditagih kreditor sesuai hasil negosiasi.

2. Saran

a. Bagi debitor yang betul-betul terkendala dalam pemenuhan kewajibannya agar menyampaikan secara terbuka pada kreditor sebagai bentuk itikad baik, dengan menyatakan dirinya mengalami imbas kesulitan keuangan karena kebijakan PSBB Covid-19. Menyampaikan kepada kreditornya sebelum dinyatakan wanprestasi bahwa ia terkena imbas PSBB Covid-19 dikarenakan hal yang langsung dialaminya.

b. Mengingat PSBB merupakan suasana baru sebagai force majeure, agar para kreditor dapat memberikan kelonggaran kepada para debitor yang terkena imbasnya.

c. Agar debitor yang kena imbas PSBB Covid-19 sebagai force majeure dapat menegosiasikan kembali kewajibannya pada kreditor untuk mendapatkan keringan dan penundaan yang memungkinkan bagi debitor dalam pemenuhan kewajibannya.

\section{DAFTAR PUSTAKA}

\section{Buku-Buku}

Badrulzaman, Mariam Darus. et all, Kompilasi Hukum Perikatan, Bandung, Citra Aditya Bakti, 2001. 
Jurnal Hukum Sasana, Volume 6 Nomor 1, Juni 2020

P-ISSN 2461-0453, E-ISSN 2722-3779

DOI: https://doi.org/10.31599/sasana.v6i1.209

Fuady, Munir. Hukum Kontrak dari Sudut Pandang Hukum Bisnis, Bandung, Citra Aditya Bakti, 2001

Harahap, M. Yahya. Hukum Acara Perdata, tentang Gugatan Persidangan, Penyitaan, Pembuktian dan Putusan Pengadilan. Jakarta, Sinar Grafika, 2008.

Hernoko, Agus Yudha. Hukum Perjanjian, Asas Proporsional dalam Kontrak Komersial, cetakan keempat Jakarta, Prenada Media Grup, 2014.

HS, Salim. Pengantar Hukum Perdata Tertulis, Jakarta, Sinar Grafika, 2005.

Kansil, C.S.T. Modul Hukum Perdata Termasuk Asas-Asas Hukum Perdata, Jakarta, Pradnya Paramita, 1995.

Marsh, S.B. and J. Solsby, Business Law, Alih Bahasa Muhammad, Abdulkadir. Hukum Perjanjian, Bandung, Alumni, 2006.

Marzuki, Peter Mahmud. Penelitian Hukum, Cetakan ke-3, Jakarta, Kencana Prenada Media Grup, 2007.

Meliala, Djaja S. Perkembangan Hukum Perdata Tentang Benda dan Hukum Perikatan, Cetakan Kedua, Bandung, Nuansa Aulia, 2008.

Muhammad, Abdulkadir. Hukum Perdata Indonesia, Bandung, Citra Aditya Bakti, 2000.

Mulyadi, Kartini. \& Gunawan Widjaja, Perikatan Pada Umumnya, Cetakan Kedua, Jakarta, Raja Grafindo Persada, 2004.

Satrio,J. Hukum Perikatan-Perikatan Pada Umumnya, Cetakan Ketiga, Bandung, Alumni, 1999

Subekti, R. Hukum Pembuktian. Pradnya Paramita, Jakarta, 1993

Suhardana, F.X. Contract Drafting, Kerangka Dasar dan Teknik Penyusunan Kontrak, Edisi Revisi, Yogyakarta, Universitas Atma Jaya, 2009.

Suryodiningrat, R.M. Azas-Azas Hukum Perikatan, Bandung, Tarsito, 1995

Sutantio, Retnowulan dan Iskandar Oeripkartawinata, Hukum Acara Perdata dalam Teori dan Praktek, Bandung, Mandar Maju, 2002.

Syahrani, Riduan. Seluk Beluk dan Asas-Asas Hukum Perdata, Bandung, Alumni, 2004.

Rasaid, Nur. Hukum Acara Perdata, Jakarta, Sinar Grafika, 1995.

\section{Sumber Lainnya}

Emirzon, Joni. Fungsi Klausula Force Majeure Dalam Hukum Kontrak Antara Teori Dan Praktik, Paper dalam Seminar Online (Webinar) yang diselenggarakan oleh Asosiasi Pengajar Hukum Keperdataan Bekerja Sama dengan Universitas Narotama Surabaya, Rabu, 22 April 2020 pukul 14.00 Sd 18.00.

Isnaeni, M. Filosofi Pengaturan Force Majeure Dalam Hukum Perikatan, Paper dalam Seminar Online (Webinar) yang diselenggarakan oleh Asosiasi Pengajar Hukum Keperdataan Bekerja Sama dengan Universitas Narotama Surabaya, Rabu, 22 April 2020 pukul 14.00 sd 18.00.

MD, Mahfud. Selaku Keynote Speaker pada Webinar Asosiasi Pengajar Hukum Keperdataan, Rabu Tanggal 22 April 2020 Jam 14.00 sd 18.00

Musjtari, Dewi Nurul. Regulasi Restruturisasi Pembiayaan Bermasalah Pada Perbankan Syariah, Paper pada Webinar yang diselenggarakan Asosiasi Pengajar dan Penelitia Hukum Ekonomi Islam Seluruh Indonesia (APPHEISI), Senin 20 April 2020 jam 14.00 sd 17.00 
https://nationalgeographic.grid.id/read/132059249/who-tetapkan-covid-19sebagai-pandemi-global-apa-maksudnya, diakses 15 April 2020

https://nasional.kompas.com/read/2020/03/03/06314981/fakta-lengkap-kasuspertama-virus-corona-di-indonesia?page=all, diakses 15 April 2020

https://www.kompas.com/sains/read/2020/03/16/200200923/kenapa-berada-dirumah-bisa-selamatkan-hidup-dari-pandemi-covid-19. Diakses 17 April 2020

https://kaltim.tribunnews.com/2020/04/17/ketika-pandemi-virus-corona-jadipertimbangan-force-majeure-bencana-nasional-begini-analisanya, diakses 18 April 2020

https://setkab.go.id/presiden-tetapkan-bencana-nonalam-penyebaran-covid-19sebagai-bencana-nasional/ diakses 18 April 2020.

https://republika.co.id/berita/q96qs2370/penundaan-cicilan-segera-berlaku-inipenjelasan-menkeu, diakses 17 April 2020.

\section{Peraturan Perundang-Undangan}

Kitab Undang-Undang Hukum Perdata

Undang-Undang Nomor 21 Tahun 2011 tentang Otoritas Jasa Keuangan

Undang-Undang No. 6 Tahun 2018 tentang Kekarantinaan Kesehatan.

Peraturan Pemerintah Pengganti Undang-Undang (Perpu No. 1 Tahun 2020 tentang

Peraturan Pemerintah No. 21 Tahun 2020 tentang Pembatasan Sosial Berskala Besar Dalam Rangka Percepatan Penanganan Corona Virus Disease 2019 (Covid-19)

Keputusan Presiden No. 12 Tahun 2020 tentang Penetapan Bencana Nonalam Penyebaran Corona Virus Disease 2019 (Covid-19) sebagai Bencana Nasional

Peraturan Otoritas Jasa Keuangan No. 11/POJK.03/2020 Tentang Stimulus Perekonomian Nasional Sebagai Kebijakan Countercyclical Dampak Penyebaran Coronavirus Disease 2019. 